\title{
How to control illegal wildlife trade in the Himalayas
}

\section{As Nepal's greatest natural resources approach extindion, thestakes cald hardybehigher}

\section{Ram P Chaudhary}

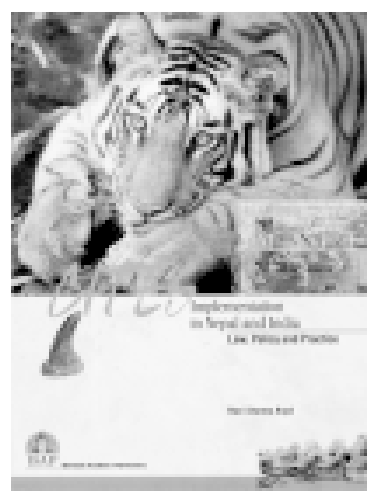

\section{Cites Implementation in Nepal and India - Law, Policy and Practice}

by Ravi Sharma Aryal

Bhrikuti Academic Publications

Kathmandu, Nepal, 2004

$200 \mathrm{pp}$

ISBN 99933-673-4-6

NRs 995, US\$ 25 (paperback)

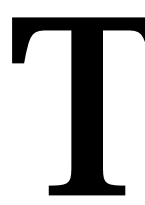

he international trade in wild animals, plants, and wildlife products is big business, with worldwidetransactions of over US\$5 billion ayear. Most of it is entirely legal, regulated bynational lawsand international treaties. Butaboutone-fourth to one-third of the trade entails unlawful commerce in rare and threatened species that are usually poached or collected illegallyand smuggled acrossfrontiers. The trade in endangered fauna and flora is diverse, ranging from live animals and plants to a vast array of wildlife products derived from them, including food products, rare and exotic leather goods, tourist curios and medicines. Such illegal trade is one of the main engines driving species to extinction.

Although population increase and poverty are generally cited as the indirect causes of poaching and illegal collection, the major threats are conflicting laws and perverseincentives on the part of rich and influential consumers. An important challenge, at present, is to systematically study the population of threatened fauna and flora so as to understand their status and conservation requirements ${ }^{1}$.

The decline in biological resources in Nepal has been due largely to the lack of policies to guide legal, institutional and operational developments in this sector. Biodiversitypolicyin Nepal hasusuallybeen shaped by political and economic motives rather than ecological and social considerations ${ }^{2}$.

An international treaty, theConvention on International Trade in Endangered Species of Wild Fauna and Flora (CITES), came into force on July 1,1975 . That same year, Nepal became a party to the treaty, and to date 165 countries have agreed to adhere to CITES. Its enforcement is the responsibility of the signatory states, and governments are required to submit reports and trade records to the CITES Secretariat.

Regulation of international trade in wildlife and wildlife products is an intersectoral endeavor, with social, economic, ecological, cultural, and political dimensions. Aryal's book covers the spectrum of issues, focusing on the gaps and weaknesses in the laws, policies, and implementation measures in Nepal and India, countries that cover a major part of the Himalayas. Aryal also discusses crosssectoral issues, which must be addressed in order to control smuggling across international borders.
Thebookis divided into seven chapters addressing a range of topics related to CITESimplementation in Nepal and India. Chapter One provides a general introduction to theconcept of endangered species, and to thestateand importanceof biodiversity. Chapter Two briefly summarizes the history of cultural and legislative efforts to protect forests and wildlifein Nepal and India. ChapterThree explains the concept and principles of CITES, discussesissues raised and progress made during the COP (Conference of Parties), and reports on typical cases of infringement of CITES in Nepal and India.

While neither Nepal nor India has drawn up specific legislation to implement CITES provisions, both countries have adopted numerous policies, laws, and conservation measures bearing on the implementation of this treaty. These are presented in Chapters Four and Five, the centerpiece of Aryal's book. Article 26.4 of the Constitution of the Kingdom of Nepal (1990) providesdirectivesfor theprotection of the environment at large; the National Parks and Wildlife Protection Act (1973), the Forest Act (1995), Nepal Biodiversity Strategy $(2002)^{3}$, and other related Actsand policiesarefulfillingtheobjectivesofCITES in Nepal. Implementation of CITES in Nepal is further strengthened by the 1991 Nepal TreatyAct (NTA) which specifies that when a matter in a treaty is inconsistent with the existing domestic laws, the domestic laws shall be void to the extent of the inconsistency, and the provision of the

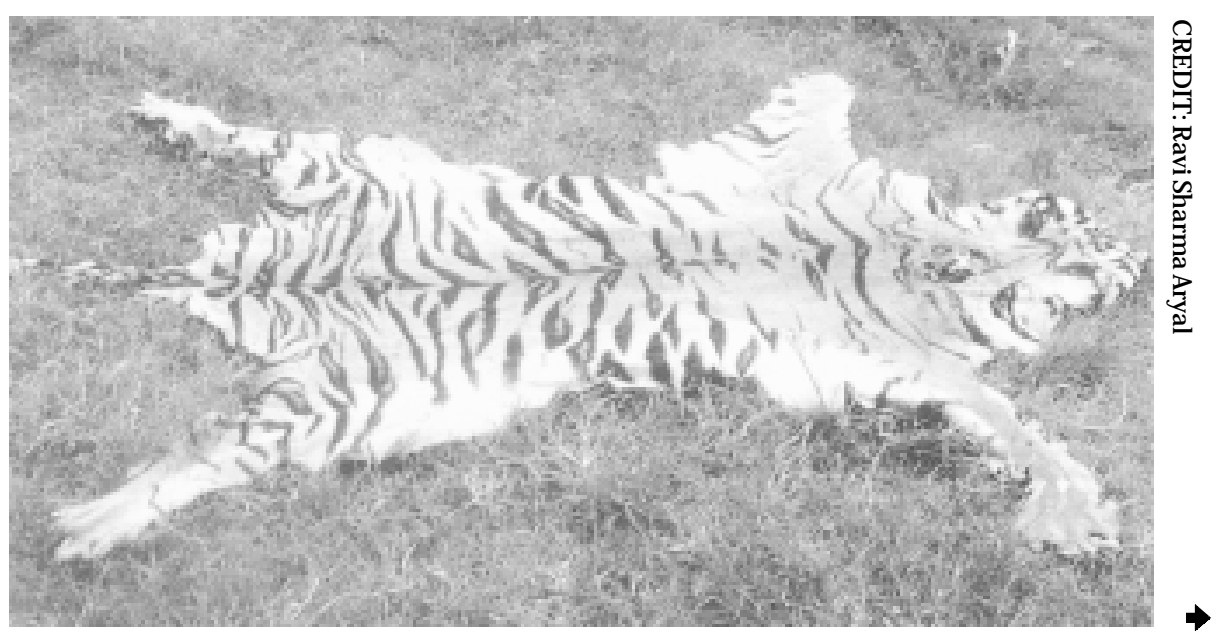


The international illegal trade in wildlife and wildlife products is one the major engines driving species to extinction. The Convention on International Trade in Endangered Species of Wild Fauna and Flora (CITES), which defines standards for use of wildlife and their products, represents a major global commitment to reverse this trend. It remains to be seen whether the terms of this treaty will be enforced. Focusing on Nepal and its neighbors, Aryal discusses the obstacles to its successful implementation: imprecise legislation, inconsistent policies, lack of coordination among relevant institutions (particularly, those responsible for regulating international trade), and the deadly threat posed by poachers determined to protect their endangered livelihoods. Aryal's recommendations are detailed, far-reaching, and compelling.

treaty shall prevail as the law of Nepal. Strangely, Aryal is silent about the Local Self-Governance Act (1998). According to this law, the District Development Committee (DDC) is the implementing body of the local government. Section 189(g) (1) of the Local Self-GovernanceAct requires the DDC to formulate and implement plans for the conservation of forests, vegetation, biological diversityand soil. Section $189(\mathrm{~g})$ (2) further requires the DDC to protect and promote the environment. Similarly, Section 28(h) (2) requires that the Village Development Committees(VDCs), thenextsmallestunit of local governance, formulate and implement programs for the conservation of forests, vegetation, biological diversity, and soil.

In Chapter Five, Aryal compiles the scattered laws impinging on control of illegal exploitation of wildlife in India. The Constitution of India as amended in 1976 (Articles 48.A and 51-A9g) directs the government to protect the environment. The Indian Forest Act of 1927, the Forest (Conservation) Act of 1980, the Biological Diversity Act of 2002 and other relevant laws areimportanttools for the protection of endangered species.

Medicinal plants, many of which are rare and threatened, are used in two ways: first, in medications prescribed by traditional systems, and second, in medications that have become accepted in Ayurvedic, Tibetan, and allopathic (or Western) medicine. In general, the collection ofmedicinal plants for traditional local use is nota problem sincethisusehas developed gradually and in harmony with nearby natural ecosystem ${ }^{1}$. Accordingly, the 1991 amendment of the 1972 Wildlife (Protection) Act of India allows scheduled tribes in India to use locally available medicinal plants in a sustainable fashion. Such protection of customary rights is not found in any Nepaleselaw, and Aryal takes issue with the provisions of the Indian Wildlife(Protection) Act. I believe, however, that through this law the government of Indiagives due recognition not only to the rights of indigenous peoples to preserve their culture, but also to theimportance of safeguarding the transmission of indigenous knowledge from one generation to another.

Aryal has rightly mentioned the importanceof transboundarycooperation. The CITES treaty could play a crucial role in the interdiction of smuggling across the Nepal-India and Nepal-Chinaborders. The protection of wildlifeiscurrently hampered by differences in the degree of protection among the three countries. For example, in China a person can besentenced to death for killing an individual of an endangered species such as the giant panda4. In Nepal and India, however, the penalty is imprisonment for few years or nominal fine or both. Tri-national consultative meetingson biodiversity conservation will bevital in plugging thegapsand untangling thelegal inconsistencies.

In Chapter Six, Aryal undertakes a review and detailed analysis of existing plans, policies, and regulations, as well as interview survey conducted in some border areas and in the capital of India about the administrative practice and constraintsin order to exposetheobstacles impeding effective implementation of CITES. The problems are diverse, ranging from lack of clarity in legislation to lack of coordination among the relevant institutions, from dubious nomenclature and out-of-date species lists to lack of competent staff in the field to threat for guards posed by the poachers.

Chapter 7, "Conclusion and Suggestion," presents Aryal's astute recommendations for improvements in strategy and administrative structure that would facilitate implementation of CITES in Nepal and India. I would cluster all the Aryal's recommendations at three levels.

Recommendations at the systemic level include:

- translation of international treaties to national legislation

- amendmentsin lawsand policieswith the view to closing existing loopholes

- strict enforcement of existing legislation

- implementation and monitoring of trans-boundary wildlife trade regulatory mechanisms.
Recommendationsattheinstitutional level include:

- developmentofstronglinkagesamong therelevantinstitutions

- development of technical infrastructure, publication and dissemination of information, and promotion of skills pertinent to CITES enforcement among police, custom officers, and immigration officials

- insulation of CITESadministration from political interference.

Recommendations at the individual level include:

- development of professional ethicsand accountability

- expanded professional networking

- enhancement of job security, benefits, and incentives, includinglifeinsurance - expanded opportunities for career advancement.

I might offer a few reservations about the bookitself. Although theprintingisof good quality, thehigh pricemaydiscouragesome readers for whom the book would be a useful reference. The small font used in thefootnotesisalso rather frustrating. The book is illustrated with photographs, a number of which are redundant. A useful supplement would be a compilation of photographs of all endangered fauna and flora listed under CITES.

Nonetheless, thebook will beavaluable resource for policy makers, politicians, wildlife traders, protected area managers, conservationists, national and international agencies, NGOs and INGOs, professors, students and general readers.

Ram P Chaudhary is a professor of botany in Tribhuvan University, Kathmandu.

E-mail: ram@cdbtu.wlink.com.np

\section{References}

1. RPChaudhary. 1998. Biodiversityin Nepal - Status and conservation. Saharanpur (India):SDevi and Bangkok:Tecpress Books. 324p

2. N Belbase. 1999. National Implementation of the convention on biological diversity: Policyand legislativerequirements. Kathmandu: Nepal. 120p

3. MFSC. 2002. Nepal biodiversity strategy. Ministry of Forestsand Soil Conservation, HMGN. 170p

4. YM Li, ZGao, XLi, SWangand N Jari. 2000. Illegal wildlife trade in the Himalayan region of China. Biod Conser 9: 901-918 